\title{
Paweł Popieliński, Mniejszość niemiecka w III Rzeczypospolitej (1989-2019) w procesie integracji ze społeczeństwem większościowym, Wydawnictwo Instytutu Studiów Politycznych PAN, Warszawa 2020, 514 s.
}

Monografia Pawła Popielińskiego, licząca 514 stron, składa się z sześciu rozdziałów, podzielonych na podrozdziały, z wprowadzenia i zakończenia. Całość uzupełniono o bibliografię, aneksy, streszczenie w języku angielskim i niemieckim oraz indeks osób.

Cezurę początkową i punkt wyjścia analiz stanowi data 14 listopada 1989 roku, czyli podpisanie przez premiera RP Tadeusza Mazowieckiego oraz kanclerza RFN Helmuta Kohla Wspólnego oświadczenia, które umożliwiało odrodzenie się i rozwój mniejszości niemieckiej w Polsce. Cezurą końcową jest początek 2019 roku, który jest rokiem jubileuszowym - 30-lecia formalnego funkcjonowania organizacji mniejszości niemieckiej w Polsce.

Analizy przedstawione w książce opierają się na badaniach jakościowych: autor w latach 2014-2015 przeprowadził 18 indywidualnych wywiadów pogłębionych z przedstawicielami mniejszości niemieckiej w różnych regionach Polski — głównie z jej liderami oraz z trzema ekspertami, zajmującymi się sprawami mniejszości, a także z przewodniczącym śląskiej organizacji regionalnej. Dodatkowo przeprowadził kwerendy w bibliotekach w Polsce i w Niemczech, wykorzystał materiały i dokumenty organizacji mniejszości niemieckiej oraz instytucji wspierających jej działalność, jak również dokonał analizy prasy (lokalnej, regionalnej i ogólnopolskiej). 
W rozdziale pierwszym pt. Polityka państwa polskiego i niemieckiego wobec mniejszości niemieckiej autor ukazał aktualną sytuację omawianej grupy na tle złożonych powojennych stosunków polsko-niemieckich, aż do 2019 roku. Przedstawione zostały główne procesy społeczno-polityczne, które w poszczególnych dekadach oddziaływały na położenie ludności niemieckiej, także te najnowsze, związane z akcesją Polski do Unii Europejskiej i obrady polsko-niemieckiego Okrągłego Stołu. Badacz zaprezentował ponadto aktywność polskich i niemieckich instytucji i organów odpowiedzialnych za realizację polityki wobec mniejszości niemieckiej. Po stronie polskiej są to: podmioty parlamentarne (sejmowa Komisja Mniejszości Narodowych i Etnicznych), instytucje i organy administracji rządowej (odpowiednie ministerstwa i departamenty), Komisja Wspólna Rządu i Mniejszości Narodowych i Etnicznych, organy administracji państwowej (Rzecznik Praw Obywatelskich) czy instytucje administracji samorządowej. Po stronie niemieckiej zaś: federalne Ministerstwo Spraw Wewnętrznych, Budownictwa i Ojczyzny, Ministerstwo Spraw Zagranicznych, urząd pełnomocnika rządu federalnego ds. kultury i mediów oraz organizacje pośredniczące.

Rozdział drugi pt. Charakterystyka społeczno-demograficzna mniejszości niemieckiej w Polsce przedstawia dynamikę przemian w strukturze społeczno-demograficznej omawianej grupy oraz czynniki wpływające na poczucie tożsamości. Autor omówił kwestię zmiany liczebności mniejszości niemieckiej w ciągu trzech dekad po przełomie 1989 roku, opierając się na wynikach Narodowych Spisów Powszechnych z 2002 i 2011 roku, a także dokumentacji poszczególnych organizacji mniejszości i ustaleniach innych badaczy. Podkreślił przy tym główne czynniki tychże zmian, tj. zagraniczne migracje zarobkowe i ich konsekwencje czy aktywność regionalnych ruchów społecznych (np. Ruch Autonomii Śląska, Stowarzyszenie Osób Narodowości Śląskiej, Stowarzyszenie Osób Narodowości Kaszubskiej - Kaszëbskô Jednota). Istotną część rozdziału stanowią rozważania dotyczące tożsamości członków mniejszości niemieckiej po 1989 roku. Badacz podkreślił zróżnicowanie i niejednorodność omawianej grupy pod względem tożsamościowym, życia religijnego (głównie w diecezji opolskiej, ale i w pozostałych diecezjach) i znajomości języka niemieckiego, której podstawą są różnice regionalne i związane z nimi odmienne doświadczenia kulturowo-historyczne. W tym kontekście ukazał specyfikę członkostwa w strukturach mniejszości niemieckiej ludności rodzimej poszczególnych regionów, np. Ślązaków, Kaszubów, Warmiaków i Mazurów.

W rozdziale trzecim pt. Działalność społeczno-kulturalna $i$ polityczna mniejszości niemieckiej autor w sposób syntetyczny zaprezentował kluczowe elementy działalności omawianej grupy, które przyczyniają się do jej integracji ze społeczeństwem większościowym. Ukazane zostały etapy funkcjonowania grupy i ewolucja kierunków działalności, jak również rozwój mediów mniejszości niemieckiej (prasa, radio, telewizja, media elektroniczne). Zaprezentowane zostało także otoczenie instytucjonalne mniejszości niemieckiej, zarówno w Polsce, jak i w Niemczech, które wspiera działalność tej grupy, między innymi: Dom Współpracy Polsko-Niemieckiej, Fundacja Rozwoju Śląska oraz Wspierania Inicjatyw 
Lokalnych, Niemieckie Towarzystwo Oświatowe, Instytut Goethego, Fundacja Współpracy Polsko-Niemieckiej. Istotną część rozważań stanowi opis działalności politycznej członków mniejszości niemieckiej, w tym ich udział w wyborach parlamentarnych i samorządowych.

W rozdziale czwartym pt. Szkolnictwo dla mniejszości niemieckiej autor przeanalizował specyfikę funkcjonowania placówek edukacyjnych mniejszości niemieckiej, w których nauczany jest język niemiecki jako język mniejszości narodowej. Ukazał przy tym uwarunkowania prawne funkcjonowania szkolnictwa mniejszości niemieckiej, kontekst wprowadzenia i oddziaływania Ustawy z dnia 6 stycznia 2005 r. o mniejszościach narodowych i etnicznych oraz o języku regionalnym, stan liczebny przedszkoli, szkół i uczniów oraz oddolne inicjatywy mniejszości niemieckiej podejmowane na rzecz rozwoju języka niemieckiego (kursy sobotnie dla dzieci, program doskonalący dla nauczycieli „Niwki”) — głównie w województwie opolskim, ale także w innych województwach.

Rozdział piąty pt. Prawa językowe osób należacych do mniejszości niemieckiej poświęcony został kwestiom prawnym wynikającym z funkcjonowania wspomnianej wyżej Ustawy z 2005 r. i innych uregulowań międzynarodowych, jak np. pisownia imion i nazwisk, wprowadzenie tablic z dodatkowymi nazwami miejscowości w języku niemieckim, język pomocniczy w urzędach. Ukazana została ewolucja realizacji praw mniejszości oraz społeczne ich postrzeganie - głównie kontrowersje i spory wokół dwujęzycznych tablic miejscowości.

W rozdziale szóstym pt. Mniejszość niemiecka w spoleczeństwie polskim. Ewolucja wzajemnych relacji i postaw autor przedstawił kwestię ewolucji postrzegania Niemców, w szczególności osób z mniejszości niemieckiej, przez społeczeństwo polskie. Przedział czasowy analiz dotyczy głównie trzech dekad po 1989 roku, które badacz osadził w szerszym kontekście historyczno-społecznym i politycznym. Syntetycznie wyjaśnił genezę i skutki funkcjonowania stereotypów, uprzedzeń narodowościowych i dyskryminacji oraz istotę relacji międzygrupowych, które ukształtowały wizerunek Niemców i mniejszości niemieckiej w społeczeństwie polskim. Cały rozdział w zdecydowanej większości bazuje na materiałach i badaniach zastanych, np. sondażach CBOS-u i wcześniejszych ustaleniach naukowców, uzupełnionych - jako egzemplifikacja procesów, opinii i postaw — o wypowiedzi respondentów, których autor badał.

W ostatniej części książki autor podsumował dotychczasowe analizy i nakreślił prognozę średnio- i długoterminową dla mniejszości niemieckiej w Polsce.

Monografia Pawła Popielińskiego jest ciekawym źródłem wiedzy o mniejszości niemieckiej funkcjonującej w III RP, z uwzględnieniem zróżnicowań regionalnych, organizacyjnych, tożsamościowych i społeczno-kulturowych. Ukazane analizy z pewnością zainteresują zarówno naukowców zajmujących się problematyką mniejszości niemieckiej w Polsce (lub szerzej problematyką mniejszościową), jak i członków mniejszości niemieckiej oraz ekspertów-praktyków aktywnych w obszarach problemowych ujętych w niniejszej książce. 